\title{
Two decades of wage developments and wage setting in central and eastern Europe
}

\begin{abstract}
This article provides an overview of wage developments and their drivers during the twenty-year transformation process in central and eastern Europe and puts this into the context of the lessons for EU accession and candidate countries. The author examines wage developments in the past period and addresses some of the contradictions that arose from the dynamic catching-up process that took place before the crisis. The article also looks at the issue of wage convergence, highlighting the paradoxical case that wage dynamism has proceeded hand-in-hand with declining union density rates and, often also, declining collective bargaining coverage rates. The ongoing crisis has questioned one of the fundamental pillars of the European idea: the income convergence of poorer countries towards the level of their rich counterparts. Much of the wage convergence that had taken place is now being questioned, while wage cuts and wage moderation are proving to be common features for central and east European countries in the post-crisis period.
\end{abstract}

Keywords: wage-setting mechanisms, EU accession, transformation, convergence, labour costs, cost competitiveness, crisis, austerity policy, foreign direct investment, labour mobility, collective bargaining, minimum wages, public sector wage policy

Main trends in wage developments in central and eastern Europe

The 1989-1990 systemic change and the following economic integration of the region of central and eastern Europe into the European and world economy had farreaching consequences for wage developments and wage-setting mechanisms. It is important to bear in mind that the de facto economic integration (free trade, free capital movements) of central and eastern Europe took place right after its opening up during the early 1990s. The accession of central and eastern European countries to the EU (the eight central-eastern European countries in 2004; Romania and Bulgaria in 2007) can be seen as a political-institutional act that completed this process by drawing these countries under the EU legislative framework. Freedom of services was extended to countries across the region at the time of EU accession, while free movement of labour is being granted in a gradual process (completed in 2011 for the 2004 accession countries; partially available, with restrictions up to 2014, for the 2007 entrants).

After an initial drop in wages due to the transformation crisis of the early 1990s, wages in central and eastern Europe started to grow dynamically from the middle of the decade, but it still took ten years for wages, in real terms, to reach their 1990 level (Figure 1 illustrates the trend, using the example of the Czech Republic). 
During the process of transformation from a closed (or shielded) planned economy towards an open market economy, developments were not linear but rather turbulent. The Czech Republic shows a comparably balanced development, in the sense that employment was rather resistant to the major bouts of turbulence, even if there was a longer-term erosion in levels of employment. Wages were subject to the most radical change, with a $30 \%$ drop in the initial phase followed by a dynamic recovery in the following ten years (in that phase, wages grew at a higher pace than GDP, while employment did not change significantly). All central and eastern European countries are common in the sense of experiencing high turbulence (Keune and Galgoczi, 2008), but some had greater employment loss (like Hungary) while others had less wage dynamism (like Bulgaria).

Figure 1 - Turbulent processes in the first decade, development of GDP, real wages and employment in the Czech Republic (\%, 1989=100)

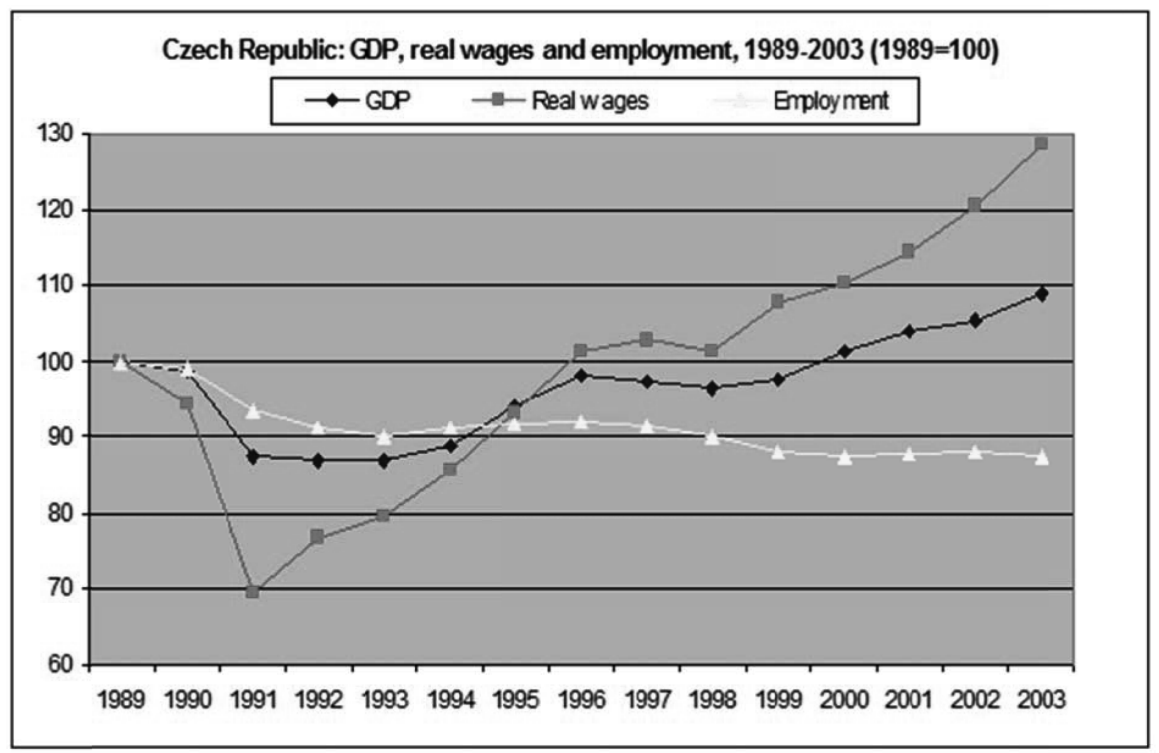

Source: Ameco database

It also matters significantly how we measure and compare wages in a dynamic environment. Examining real wage developments in a national currency (as in Figure 1 ) is the most important in the national context, and for workers and trade unions. Real wages are decisive in terms of their purchasing power, i.e. what workers can buy with their earnings. For international comparisons, the wage levels of different countries are compared in foreign exchange (in Europe, mostly in Euros). This can be done at the market exchange rate (the most common method), but also at an exchange rate that takes into account the price differences between countries (exchange rate at purchasing power parity). If we want to illustrate the differences between living standards in dif- 
ferent countries, the best way is to compare wages in terms of purchasing power parity. For international competitiveness, however, comparisons using the market exchange rate remain relevant. Wages of central and east European countries expressed in Euros are indicative for foreign investors, because this determines labour costs (more precisely, the labour cost advantage from which they can benefit). This is where the differences between west European rich countries and their poorer eastern counterparts appear to be the greatest, as Figure 4, using 2010 data, indicates. Also, the dynamism of relative wage increases is highest when examined using foreign exchange at the market rate, as Table 1 illustrates.

The catching-up process when it comes to wages is especially spectacular when expressed in Euros (instead of national currency). Besides the real wage increases here, we also have the effect of an appreciating exchange rate and higher inflation in central and eastern Europe. For the Czech Republic, this results in an increase in its relative wage level (in Euros) compared to Germany, from $7.1 \%$ in 1993 to $44 \%$ in 2010, as Table 1 reports:

Table 1 - Wage catching-up of Hungary and the Czech Republic with Germany $(\%$, in $€)$

\begin{tabular}{|l|c|c|c|}
\hline & $\mathbf{1 9 9 3}$ & $\mathbf{2 0 0 3}$ & $\mathbf{2 0 1 0}$ \\
\hline Hungary & 10.5 & 19.6 & 34.5 \\
\hline Czech Republic & 7.1 & 19.5 & 44.0 \\
\hline Germany & 100.0 & 100.0 & 100.0 \\
\hline
\end{tabular}

Source: European Commission, 2011

The second decade (2000-2010) has brought clear convergence between central and eastern Europe and core west European countries in terms of wages. Real wages practically stagnated in Germany during the whole decade, but in central and east European countries they characteristically grew in a range between $35 \%$ and $75 \%$, with Romania outpacing all other countries with an increase of $115 \%$ (Figure 2 shows real wage developments in all central and east European countries compared to Germany). Real wages grew dynamically up to the point of the crisis but, even with the downwards correction at the end of the decade, the increase was substantial.

This reversal of the catching-up process in 2008-2009 raises serious questions about convergence, most particularly the degree of wage convergence between richer and poorer countries that was always seen as one of the major strengths of the European integration project.

A considerable wage gap, however, still remains. Figure 3 shows the absolute levels of compensation of employees for 2010 across European Union member states, in Croatia (a member from 2013) and in Norway. Even if 'compensation' also includes the social security contributions paid by employers on the basis of the gross wage, the figures give good guidance as to the degree of wage dispersion at European level. Even with the catching-up process of the previous decade, wage differences between new and old member states remain substantial. On average, central and east European coun- 
tries had wage levels at c. $35 \%$ of the EU-27 average; the biggest difference within the EU is seen between Bulgaria and Luxembourg (the latter having a wage level more than ten times higher than the former). Norway is not a member of the EU, but it has the highest wages in the entire European Economic Area (EEA).

Figure 2 - Real wage developments in central and east European states and Germany (2000-2010)

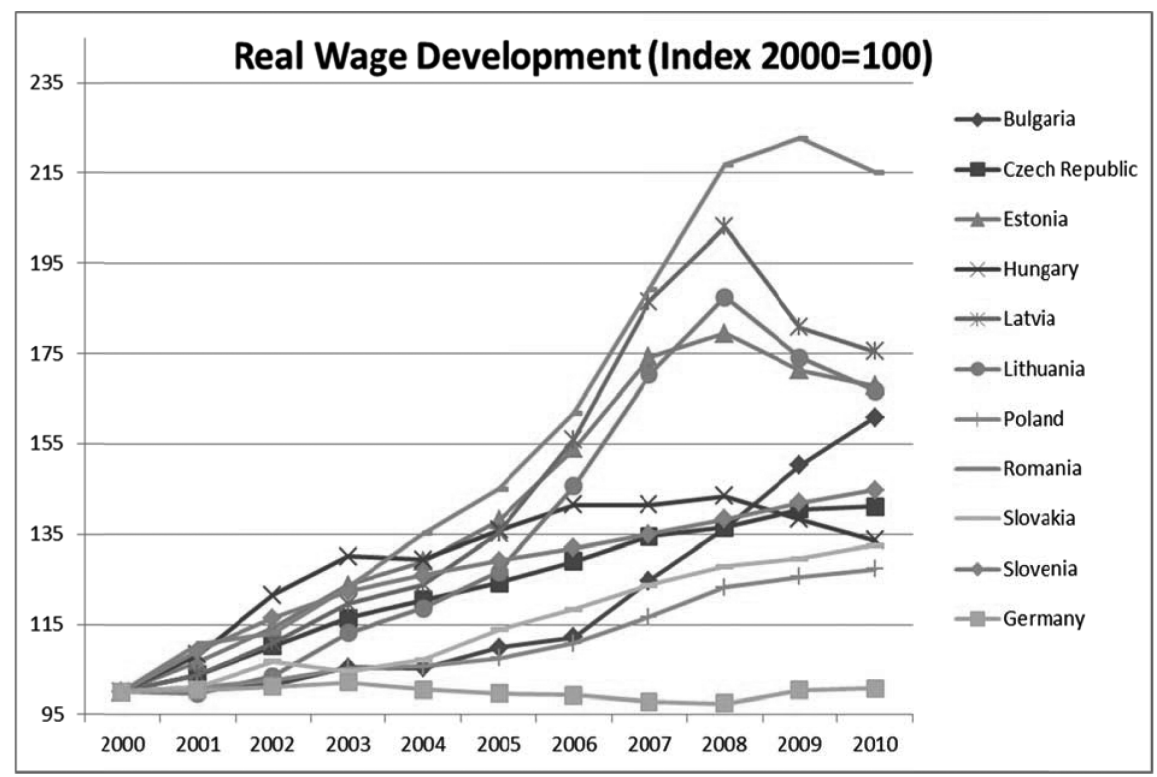

Source: Ameco database 
Figure 3 - Yearly compensation per employee $(€, 000)$

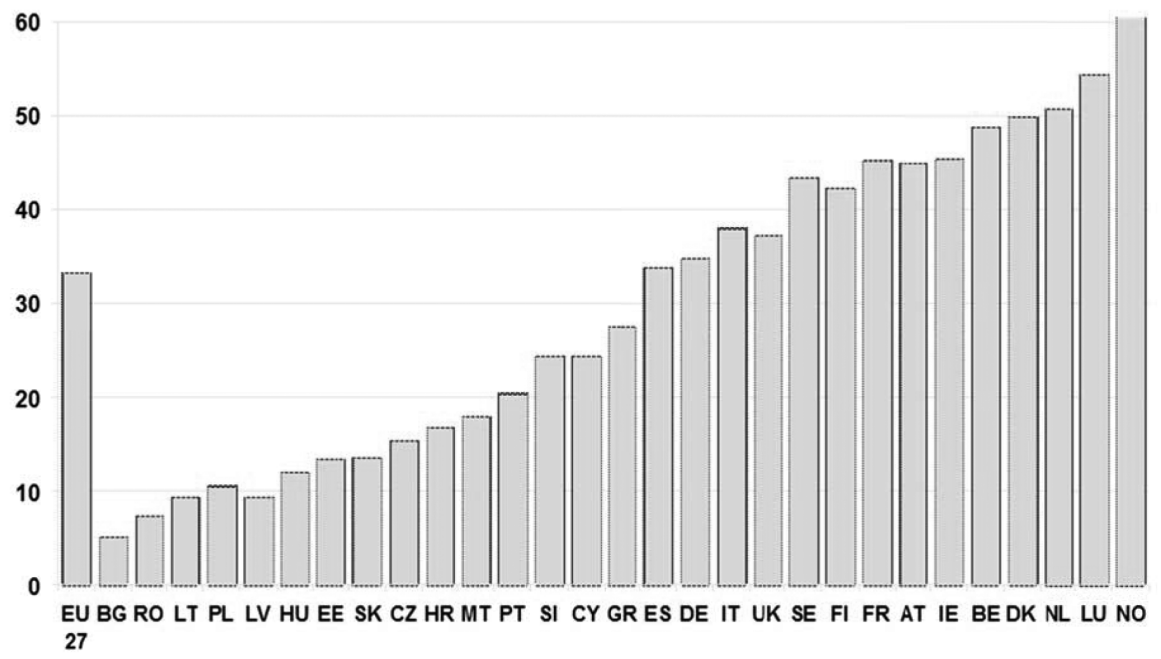

Source: Ameco database. Note: compensation includes wages and employers' social contributions

When comparing national economies from the point of view of international competitiveness, unit labour costs is the most commonly used measure.

Unit labour costs include the effects of productivity since they give an indication of the relationship between wages and productivity. Figure 4 shows the development of unit labour costs, on the one hand for those central and east European countries which are members of the Eurozone (Estonia, Slovakia and Slovenia), as well as Poland, and, on the other, those for Germany alongside two Eurozone crisis countries (Greece and Portugal). In the context of the current Eurozone crisis, it is argued that the divergence in nominal unit labour costs between Germany and countries like Greece and Portugal has widened to unsustainable levels and contributed to the current crisis. 
Figure 4 - Development of total unit labour costs in southern and eastern Europe with Germany as reference

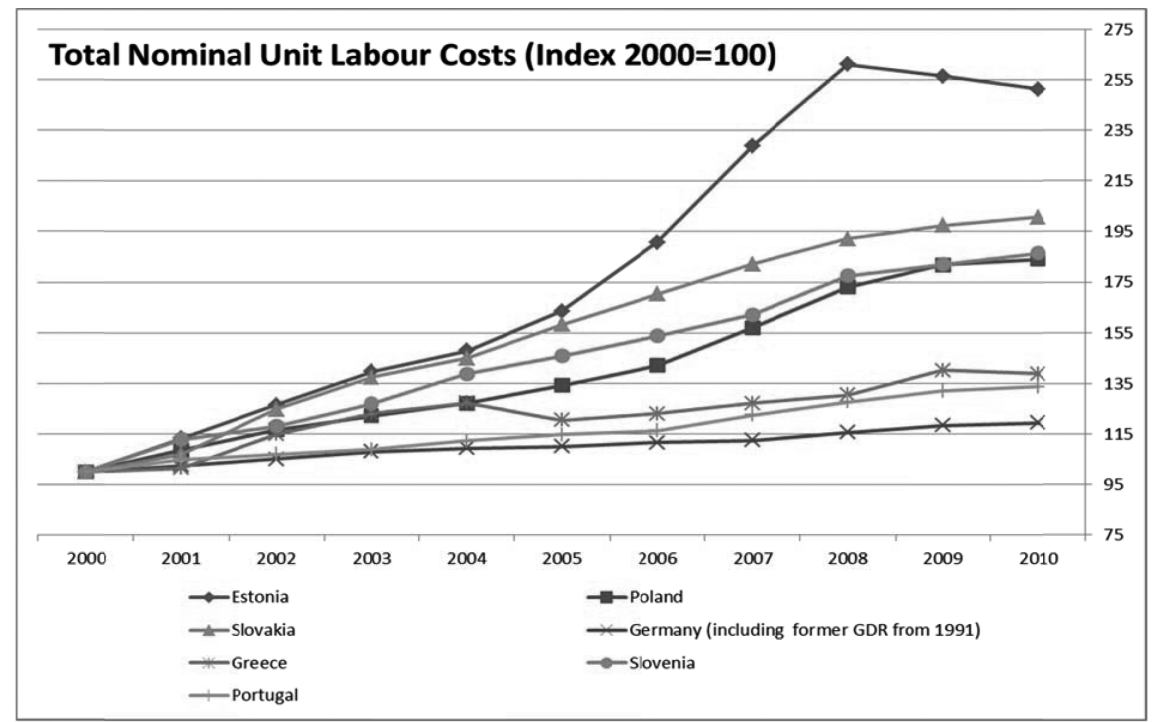

Source: Ameco database.

Nominal unit labour costs grew by around $35 \%$ in Greece and Portugal compared to Germany, but in central and east European countries they showed an increase ranging between $80 \%$ and $90 \%$, while in Estonia they grew by as much as $150 \%$.

This raises the issue that, if Greece and Portugal have major competitiveness problems, then these central and east European countries with a much higher increase in unit labour costs must have had their competitiveness wiped out. We will show later that, at least to some extent, the European Commission believes this to be true and is exerting pressure for wage cuts in many central and east European economies.

We will also show that, in contrast, this is not necessarily the case. Central and east European countries have some specific features, but we also demonstrate that unit labour costs are not a general measure of competitiveness (Felipe and Kumar, 2011).

Within central and eastern Europe, no such comparable loss of competitiveness has occurred, since trade balances, export performance and market share all show gains, as highlighted by the 2011 Annual Growth Survey (European Commission, 2011). Part of the answer to this comes from the nature of transformation economies. Wage levels are still a fraction of those in the EU-15, and so productivity increases, especially in export manufacturing sectors, provide a 'productivity reserve' and, therefore, some room for upwards wage convergence.

The share of wages in GDP are an important measure of how the wealth that is created by an economy (in terms of GDP) is distributed between labour and capital and, thus, provide a broad indication of the share of labour within an economy. In most 
countries in western Europe, wage shares have been falling during the last two decades, whereas wage shares in central and eastern Europe give a more mixed picture without such a clear downwards trend (Janssen, 2013).

The overall level of the wage share, in spite of the longer-term downwards trend, is still clearly higher in west European countries than in those of central and eastern Europe, as Figure 5 shows (ETUC-ETUI, 2012). This gives us an indication that, not only do the latter have, on average, wage levels which are one-third of those of the EU-27, but also a wage share of GDP which is lower by c. five percentage points. Wage levels in central and eastern Europe are, therefore, even lower than their level of economic development would assume. This is one indication why they do not have a fundamental cost-competitiveness problem, in spite of high wage increases in the past.

Figure 5 - Adjusted wage share in GDP by group of EU countries, 2008-2012 (\%)

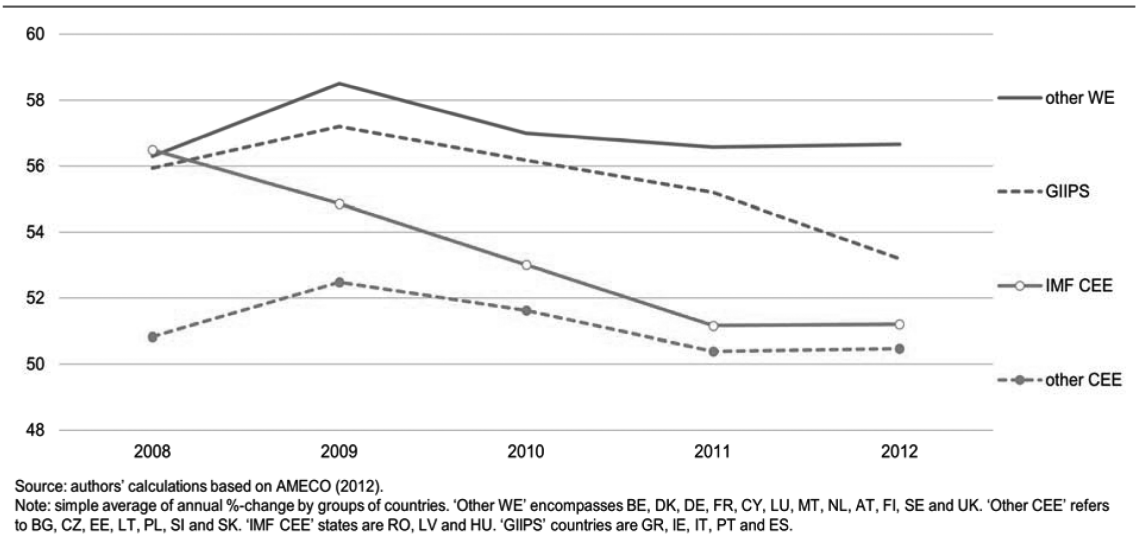

In the next section, we also show that, when the effect of productivity is taken into account, neither do we find an indication of a competitiveness problem. We also show that the 'mechanical' use of yearly unit labour cost changes at the level of the whole economy (which is what the European Commission does) is mistaken as a measure of competitiveness.

\section{The crisis and the effects of austerity policy on wages}

There are new risks to the process of wage convergence in Europe that was clearly taking place in the period up to the crisis. Paradoxically, it was less the effect of the acute crisis in 2009 and 2010 that marked a turning point, but more the applied austerity policy in Europe and the macroeconomic surveillance mechanism introduced within the European Semester that is keeping the pressure on wages. According to these policy recommendations, that also appear as hard constraints on national policy-makers, the wage increases of the past are not sustainable and that central and eastern Europe, similar to the southern periphery of the Euro area, has lost its competitiveness. A downwards wage correction is, therefore, on the agenda. In the case of those countries where financial help in the form of an IMF-EU bailout has been provided (in Latvia, 
Hungary and Romania as regards central and eastern Europe), wage cuts have often been among the conditions of the provision of stand-by credit facilities. In other countries, such pressure has appeared in a more indirect way but most of them have been subject to wage corrections.

\section{Is cost competitiveness indeed an issue for central and eastern Europe?}

Wages in central and east European countries rose dynamically in the decade before the crisis, but this does not automatically mean that these wages are too high and need to be cut back.

Export dependence appeared to be as a risk factor during the 2009 crisis in central and eastern Europe, and doubts have been raised about the sustainability of these countries' export-based and FDI-driven growth model, but the case of southern European countries in the 2010 Euro-area crisis showed that it is the lack of such an export potential that leads to even bigger problems. Apart from the fiscal element of their difficulties, Greece and Portugal suffer from a longer-term lack of export competitiveness that is also apparent from the accumulating imbalances within the rest of the Euro area. During the last ten years, these two countries lost competitiveness vis-à-vis Germany, as their unit labour costs rose substantially higher than did those in Germany (with wages increasing faster than productivity). But, as we saw in Figure 1 and in the section on wages above, the new member states in central and eastern Europe saw even greater increases in their relative unit labour costs compared to Germany.

Some southern European crisis states may have a long-term competitiveness problem, but this is not the case for most central and eastern European countries. Table 2 shows some key competitiveness indicators based on the European Commission's Annual Growth Survey (European Commission, 2011) and on Eurostat data.

It focuses on the relation between gross wages in the business sector and productivity at the level of the economy as a whole (both measured at purchasing power standards, PPS), and it sets these figures in comparison with Germany. The figures reveal that wage levels relative to productivity are lower in all the examined countries than they are in Germany (relative wages are lower than relative productivity).

The real effective exchange rate - the key indicator of competitiveness in the eyes of the European Commission - shows the combined effects of exchange rates, inflation, nominal wages and developments in productivity (a higher positive figure shows a loss of competitiveness). What we see here is that Slovakia and the Czech Republic seem to have lost cost competitiveness on the largest scale, followed by Hungary. Greece and Portugal, according to this indicator, also show a loss of competitiveness but to a smaller extent. 
Table 2 - Key indicators for selected central, eastern and southern European countries, with Germany as a reference

\begin{tabular}{|l|c|c|c|c|}
\hline Country & $\begin{array}{c}\text { Gross annual } \\
\text { wage per } \\
\text { employed, } \\
\text { business sector } \\
(\boldsymbol{\epsilon}, \text { PPS) }\end{array}$ & $\begin{array}{c}\text { Wage level in } \\
\text { business sector } \\
\text { at PPS (\% of } \\
\text { Germany) }\end{array}$ & $\begin{array}{c}\text { Labour } \\
\text { productivity, } \\
\text { total economy, } \\
\text { Germany = 100 }\end{array}$ & $\begin{array}{c}\text { Real effective } \\
\text { exchange rate, } \\
\text { \% difference } \\
\text { from long-term } \\
\text { average }\end{array}$ \\
\hline Czech Republic & 15575 & 38.5 & 68.5 & 41.5 \\
\hline Hungary & 16737 & 41.4 & 67.1 & 13.0 \\
\hline Greece & 31784 & 78.7 & 93.6 & 12.8 \\
\hline Germany & 40364 & 100.0 & 100.0 & -5.8 \\
\hline Portugal & 20371 & 50.4 & 70.7 & 8.7 \\
\hline Slovakia & 16316 & 40.4 & 75.2 & 54.2 \\
\hline
\end{tabular}

Source: European Commission, 2011; Eurostat

All the Commission's analyses of competitiveness take only annual changes into account, with the underlying assumption that the year of reference (usually 2000) was a 'golden year of harmony' and equilibrium. In terms of annual changes in the real effective exchange rate, both the Czech Republic and Slovakia indeed lost cost competitiveness to a certain degree, but this does not necessarily mean that they became non-competitive, given also that their wage levels - also in relative terms to productivity - are still low. Both their trade balances and their growth in market shares show that this was not the case.

Table 3 offers an alternative indicator of wage-adjusted productivity across EU member states by taking a ratio between apparent labour productivity and average personnel costs in manufacturing, and making a cross-country comparison. The first feature demonstrated by these data is that the divergence in levels is much smaller here than is suggested by the evidence based solely on developments in unit labour costs over time. The second interesting result is that Germany shows the lowest value in wage-adjusted productivity compared to the other countries under examination. What this means in concrete terms is that, in German manufacturing, for wage costs of $€ 1000$, $€ 1207$ was produced in terms of value added; while in Hungary the figure was $€ 1996$ and, in Greece, $€ 1506$.

Combining these two factors into a wage-adjusted labour productivity ratio shows that value added per person employed was equivalent to $132.1 \%$ of average personnel costs per employee in manufacturing within the EU-27; and that the ratio was higher than this in the countries of southern, central and eastern Europe. 
Table 3 - Wage-adjusted productivity in manufacturing in selected countries, 2009

\begin{tabular}{|c|c|c|c|}
\hline \multirow[t]{2}{*}{ Country } & $\begin{array}{l}\text { Apparent labour } \\
\text { productivity* }\end{array}$ & $\begin{array}{l}\text { Average personnel } \\
\text { costs }\end{array}$ & \multirow[t]{2}{*}{$\begin{array}{l}\text { Wage adjusted } \\
\text { productivity (\%) }\end{array}$} \\
\hline & \multicolumn{2}{|c|}{ (€1 000 per employed) } & \\
\hline EU-27 & 46 & 34.5 & 132.1 \\
\hline Czech Republic & 22 & 14.0 & 154.6 \\
\hline Hungary & 23 & 11.7 & 199.6 \\
\hline Greece & 42 & 28.0 & 150.6 \\
\hline Germany & 57 & 47.2 & 120.7 \\
\hline Portugal & 23 & 15.8 & 146.7 \\
\hline Slovakia & 17 & 12.3 & 134.7 \\
\hline Spain & 48 & 35.1 & 137.2 \\
\hline
\end{tabular}

Source: Eurostat, 2012

http://epp.eurostat.ec.europa.eu/statistics_explained/index.php/Manufacturing_statistics_-_NACE_ Rev._2

*apparent labour productivity is defined as value added at factor cost divided by the number of people, employed

One of the lessons that can be drawn from the above evidence/data is that the 'peripheral' countries have, due to increasing unit labour costs, gradually lost cost competitiveness over time, but this does not necessarily mean that their competitiveness has dwindled to nothing; for they remain competitive by virtue of their relatively low income (and wage) levels, and this is particularly true of central and east European countries. Slovakia has, in recent years, been losing cost competitiveness at a record level within the EU (see the real effective exchange rate data in Table 2), but it retains, nonetheless, a reasonable level of competitiveness, as can be seen from its relative wage-adjusted productivity levels but also from its trade surplus and its export performance.

Furthermore, if some southern European countries undoubtedly do show signs of a lack of competitiveness, the data on relative wage and productivity levels at least suggest that, underlying this shortcoming, there are a number of structural reasons which exist over and above any mere cost factor. Tackling these structural problems through cost adjustments (wage and spending cuts) can deliver temporary results in cost competitiveness at the price of a dramatic increase in poverty and unemployment but, in the end, these inevitable side-effects also jeopardise the success of the entire adjustment. Cost adjustment is simply not an adequate way to address longer-term structural problems (such as the share of manufacturing in the whole economy, export shares, the qualitative composition of exports, a country's place in the international 
division of labour, etc.). We have seen above that these countries are not competing in export markets with eastern Europe or Germany.

The problem, to put it bluntly, is not that consumers in the surplus countries have been buying less olive oil and port wine due to rising unit labour costs in Greece or Portugal. In other words, the cure chosen to date is one that tackles the symptoms but not the causes of the problem.

\section{Drivers of wage increases in CEE}

When looking into the background of these wage dynamics, we cannot point to a single well-identifiable factor.

\section{Economic drivers of wage increases}

What we see as a longer-term development is that economic integration between regions of huge income and wage differences induces a levelling-out process. This results in a strong drive for wage increases in central and eastern Europe through two major channels: foreign direct investment (FDI); and labour mobility.

Both foreign direct investments and labour mobility have had an impact on wage developments in central and eastern Europe. Figure 6 shows that the stock of foreign direct investment makes up a high share of the GDP of individual countries in central and eastern Europe, of characteristically between $60 \%$ and $80 \%$ (ETUC-ETUI, 2013).

Figure 6 - Inward foreign direct investment stock in selected years, 1995-2011 (\% of GDP)

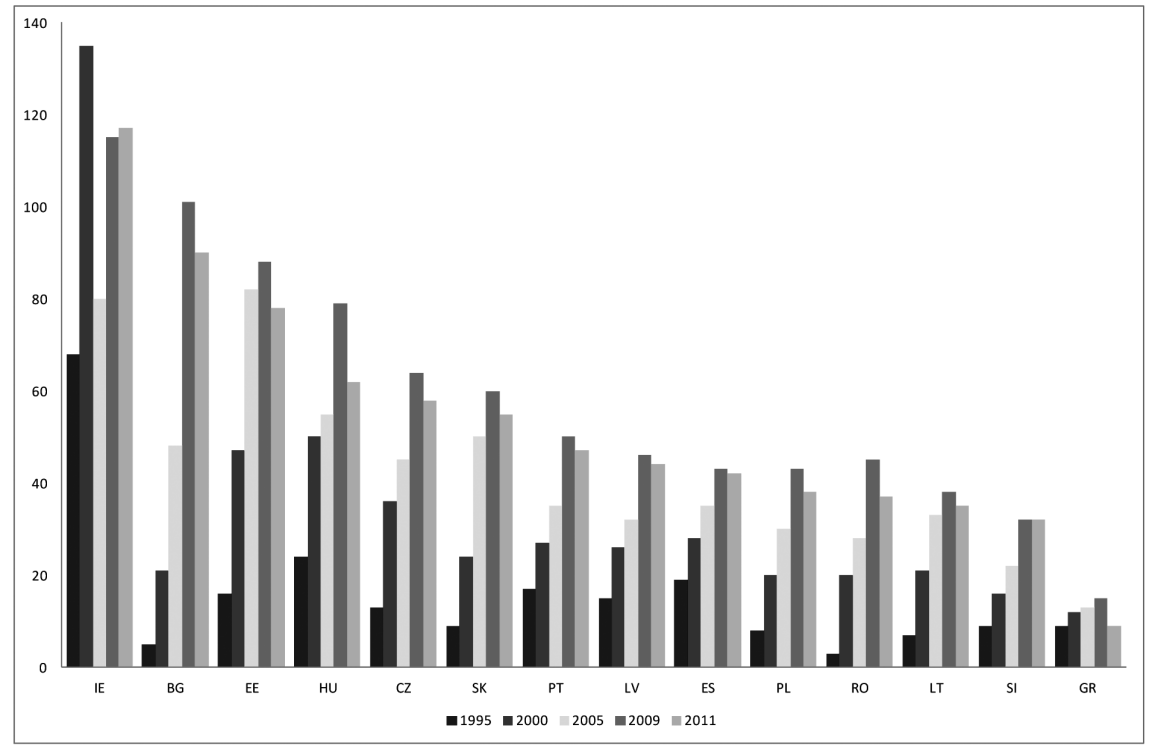

Source: UNCTAD (2012) 
Foreign direct investments, and especially the kind that target the export manufacturing sector, have played a key role in modernising the industrial base of countries in central and east Europe. They brought new technology and work organisation and were in need of skilled labour. High productivity, export-driven foreign investment enterprises pay higher wages than the national and regional average and, with the more difficult availability of skilled labour, wages rise rapidly. Foreign investment enterprises have a large share of the economy of most central and eastern Europe companies and so they exert a 'pull' effect on general wage levels in the economy.

The dramatic increase in labour mobility after enlargement (2004) is a second important factor which has had an upwards effect on wages in the countries of central and eastern Europe.

Figure 7 - EU-8 migrants in the populations of receiving EU-15 countries (stocks, 000)

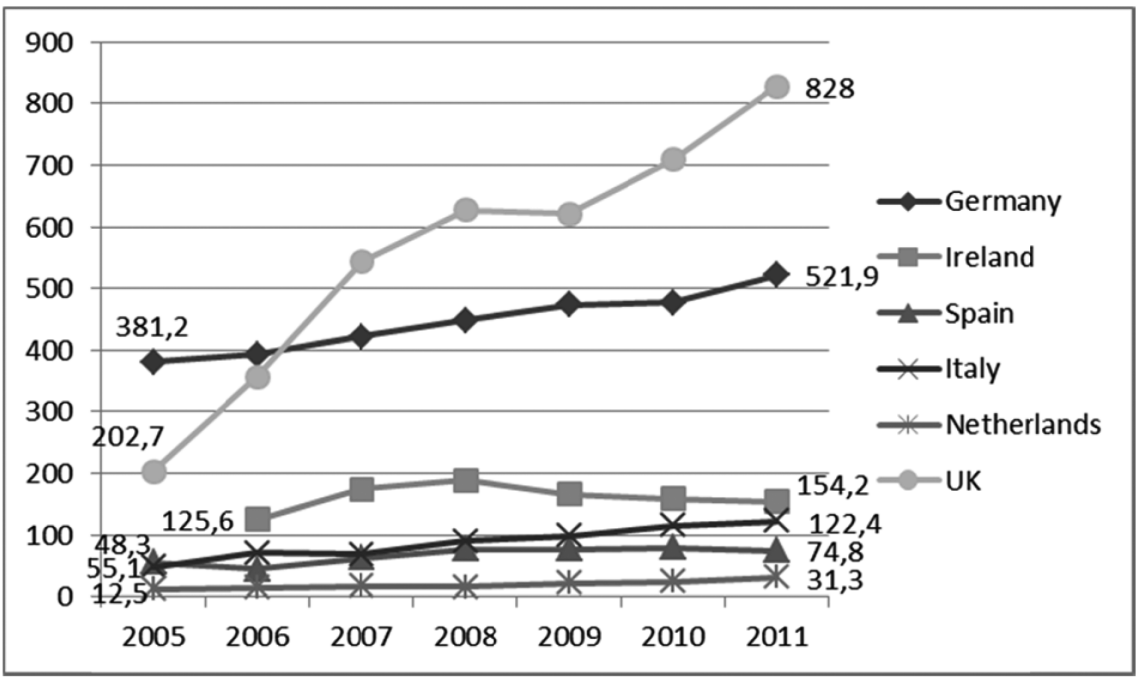

Source: EU LFS data 2011.

Labour mobility has had a similar impact since, from 2004, when eight countries from the region joined the EU and the old member states opened their labour markets (some gradually), millions of citizens of central and eastern European countries have found jobs in western Europe (Galgoczi and Leschke, 2012). The most important 'pull' factor in labour mobility was the higher wage levels available in the west. Large-scale outwards migration from certain countries (particularly Poland, Romania and the Baltic states) resulted in labour market bottlenecks in certain sectors (teachers, doctors, nurses and bus drivers have often been hard to recruit), with the consequence that wages in these sectors started to grow, often also due to the influence of policy considerations. Trade unions saw greater opportunity for bargaining for higher wages, while wages in certain public sector professions were also raised by the state. In certain periods, this 
reflected an element of policies which were targeted at return migration (offering migrants attractive return opportunities). ments.

This phenomenon led to an increase in wages in the respective labour market seg-

\section{Wage-setting and collective bargaining in central and eastern Europe}

Collective bargaining structures in central and eastern Europe are rather weak while collective bargaining coverage rates (with the exception of Slovenia) are low. Autonomous collective bargaining was a new phenomenon in the region after the system change in 1989-1990; in the previous system of 'state socialism', trade unions characteristically acted as the 'transmission belt' of the policies of communist parties (although with a weakening trend in the 1980s). The democratic change swept away these structures, thus creating the institutional basis for autonomous collective bargaining. This was, however, a top-down process, in contrast to the decade-long period of organic development that took place in post-War western Europe.

Figure 8 - Trade union density in EU-27, Norway and Switzerland: comparing 2004-7 with 2008-11 (averages)

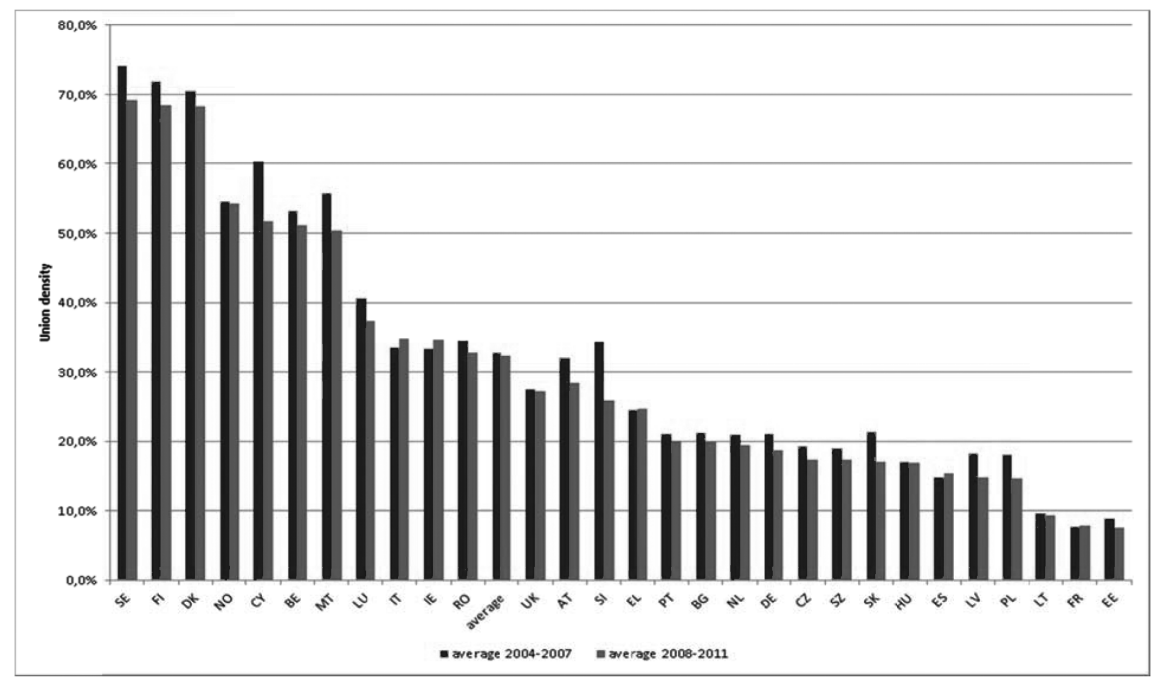

Source: Visser (2012) ICTWSS database.

The structures and institutions of collective bargaining were shaped by the transformation in 1989-1990. National-level institutions had become dominant (such as, for example, national-level interest representation bodies involving trade unions, employer organisations and representatives of the government). These bodies played a central role in the socio-economic transformation process where a corresponding legislative framework had been set up (labour codes, labour market and social policy institutions). 
This process led to a different structure for industrial relations than is the case in western Europe, where bilateral (employer/trade union) bargaining is dominant at the industry level. In contrast, industry-level multi-employer bargaining has remained weak in central and eastern Europe which has, on the one hand, a relatively strong national tripartite negotiation level and, on the other, weaker company level bargaining.

In the practice of most countries in central and eastern Europe, a general framework for wage developments is set at the national level (a minimum wage and a national wage recommendation) and this is applied at company level (where trade union organisation exists). Trade unions are not represented in the majority of enterprises, and branch-level bargaining is patchy (with the exception of Slovenia), so collective bargaining in central and eastern Europe exists on a rather weak and further eroding basis (Figure 4 shows collective bargaining coverage rates in Europe).

Figure 9 - Collective bargaining coverage rates in Europe, 1997/1999 vs. 2007/2009

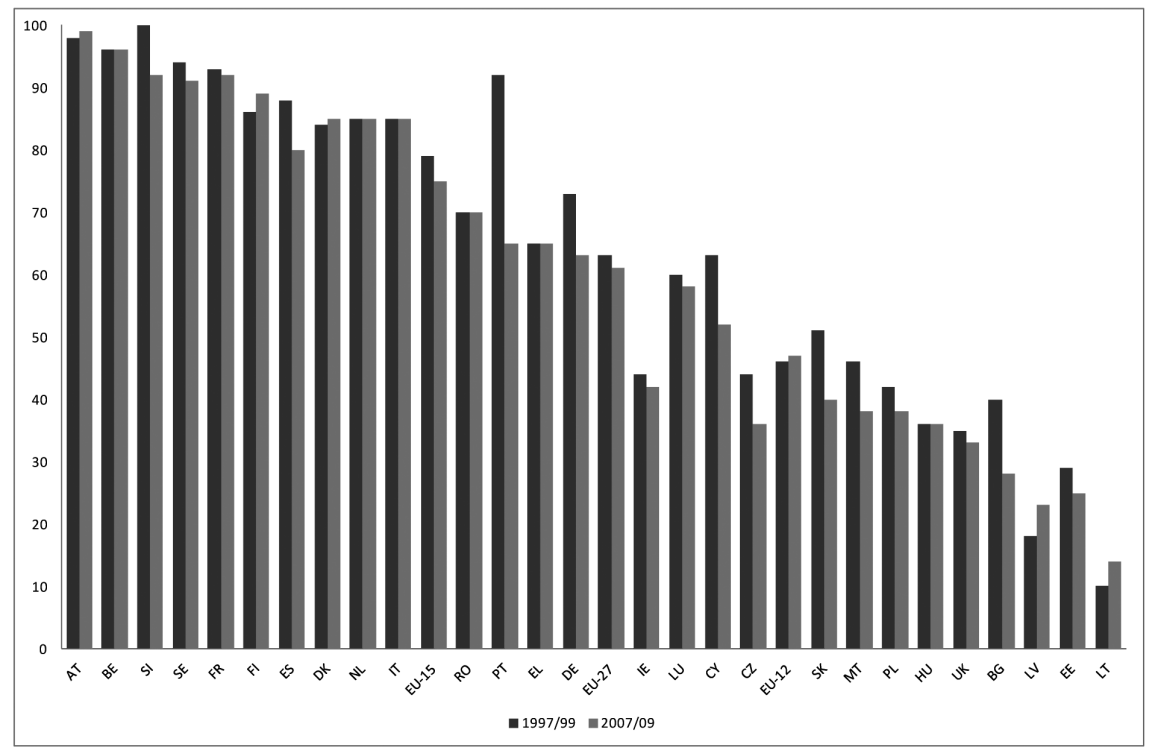

Source: Visser (2012) ICTWSS database.

The weak role of collective bargaining in the wage-setting process can also be demonstrated by a persistent positive wage drift between bargained and actual wages in central and eastern Europe. The actual wage increases in countries of the region tended to be higher than the wage increases settled through the bargaining process. This also indicates that other factors than bargaining also play a role. Particularly in Germany, the main trend has, in, in contrast, been the opposite: actual wages were regularly lower by the end of the year than what had been bargained between unions and employers (the concept of negative wage drift). 


\section{Minimum wages and related policies}

Each country in central and east Europe has a statutory national minimum wage. This is settled in tripartite national negotiations at the national level. In most cases, the government plays an observer role and accepts the bargaining result reached by the employer federations and the trade unions. In certain countries, the government has the right to determine the minimum wage if the social partners are not able to reach agreement before a fixed deadline.

Minimum wage policy had played a substantial role in a number of countries (Hungary, Czech Republic and the Baltic states) also as regards general wage levels in the respective countries. In these cases, there were periods when significant increases in the national minimum wage have been decided upon (often inspired by the government) as a means of easing social tensions, with the intention also of pushing up wage rates and bringing in more revenue for the state (the social security contributions of individual entrepreneurs are often linked to the minimum wage, while certain welfare schemes set the national minimum wage as a reference value).

National minimum wage levels in central and eastern Europe are substantially lower than in the old member states, as Figure 9 for 2009 and 2010 indicates.

Figure 10 - National-level statutory monthly minimum wages in the EU (2009 and 2010, €)

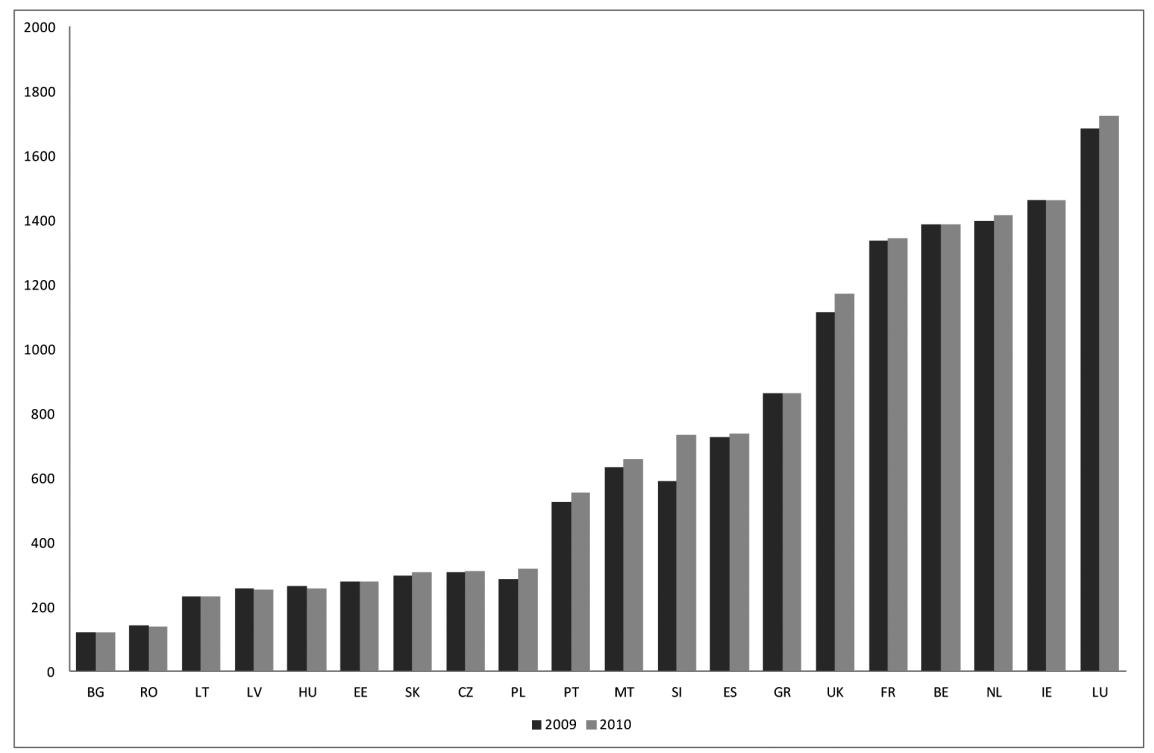

Source: Eurostat, 2011; ETUC-ETUI, 2011.

Figure 11 shows real changes in the hourly minimum wage in the EU over the last three years. We see a highly dispersed picture, with a few countries in central and 
eastern Europe (Czech Republic, Romania and Latvia) having seen decreases in the minimum wage in the last two years while, in the case of others (Poland, Bulgaria and Latvia), minimum wages have grown substantially.

Figure 11 - Changes in real hourly minimum wages in the EU (2010, 2011 and 2012)

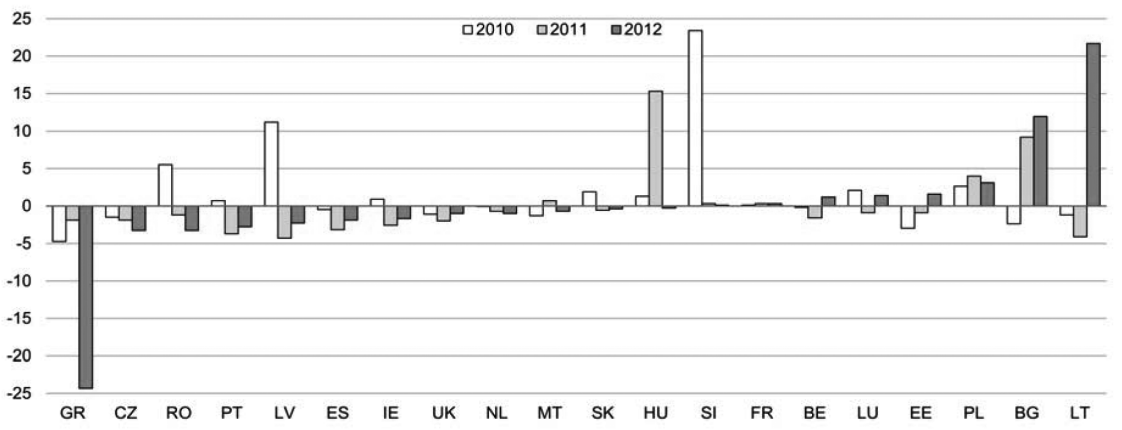

Source: WSI Minimum Wage Database (2013).

Note: annual \%-change in relation to the previous year. For countries outside the eurozone, calculations are made on the basis of national currencies.

\section{What did drive wage increases then, finally?}

The main driver of wage increases was, therefore, a mix of market-based forces due to economic integration and, to some extent, minimum wage policy and wage-related policy measures in the public sector.

It can clearly be questioned whether the dynamics of this process would be sustainable after the crisis.

\section{Conclusions}

Central and eastern European countries have gone through a difficult and turbulent transformation process in the last twenty years. In the post-war bipolar world, Europe used to be divided both in political and economic terms. Following the collapse of this order, the countries of the region felt themselves to be liberated and they abandoned the post-communist planned economy. The market economy has been established and countries have been integrated into the European and world economy. This did not result in a linear development process, as trade and industrial structures collapsed, unemployment started to soar and wages plummeted. It was only from the mid 1990s that the region started to catch up with the richer countries of western Europe. The modernisation of these economies was driven by foreign direct investment and this was also the driving force behind dynamic wage increases.

Trade unions went through a fundamental democratisation process; from the role of 'transmission belt' for the ruling communist parties before 1990, they went through fundamental institutional changes while new independent unions were also established. Unionisation rates of almost $100 \%$ before the regime change were not expected to be sustainable, but the dramatic drop in union density that followed was still surprising. 
Trade unions remained weak and collective bargaining coverage relatively low. Trade unions were mostly active at the tripartite national level and in companies. Sectoral bargaining - the dominant level of collective bargaining in continental western Europe - has remained weak. We have shown that wage increases were primarily driven by economic processes, foreign direct investment and outwards labour mobility. Minimum wage policy and wage-setting in the public sector have also played a role in certain periods.

The crisis has, however, highlighted the fragility of the integration model that had previously helped central and east European countries achieve a considerable degree of convergence towards western Europe in the pre-crisis period. FDI-driven exportbased growth, concentrated in cyclical industries, did indeed prove to be a risk factor during the downturn, but the quick rebound in exports following the crisis also appears to indicate the relative resilience of this economic model. The major challenge for these countries is to develop innovation and knowledge-intensive activities that would allow them to sustain the convergence trend in the long-term. Central and eastern Europe cannot continue to rely on cost competitiveness given, among other things, competition from the large pool of cheap labour in south-east European countries. They do not have a fundamental cost competitiveness problem, but the pressures for wage moderation, and even wage cuts in certain countries, remain high.

It has been taken for granted that European integration would bring economic and wage convergence, but this is now being questioned. One thing is sure: these countries cannot rely on low wage competitiveness in the long-run; the way ahead is through increased public investment in education and research and improvement in the quality of the institutional environment.

The crisis has also highlighted the weaknesses of industrial relations. In good times, with dynamic economic development, wages were growing without powerful trade unions. Now that times are different, and both national governments and the European institutions are pushing for austerity and wage moderation, trade unions do not have the necessary negotiating and mobilisation power to resist.

\section{References}

ETUC-ETUI (2012) Benchmarking Working Europe 2012 Brussels.

ETUC-ETUI (2013) Benchmarking Working Europe 2013 Brussels.

European Commission (2011) Annual Growth Survey Brussels.

Eurostat (2012) Statistics Explained: Manufacturing statistics Luxembourg, available at: http://epp.eurostat.ec.europa.eu/statistics_explained/index.php/Manufacturing _statistics_-_NACE_Rev._2

Felipe, J and U. Kumar (2011): Do some countries in the Eurozone need an internal devaluation? available at: http://www.voxeu.org/article/internal-devaluations-euro zone-mismeasured-and-misguided-argument 
Galgoczi, B and J. Leschke (2012): Intra-EU labour migration after eastern enlargement and during the crisis Working Paper, ETUI: Brussels.

Janssen, R (2013) Trends in wage shares ETUC: Brussels.

Keune, M and B. Galgoczi (2008): Collective bargaining on wages ETUI: Brussels. 